\title{
The Gospel as Literary Genre and Form of Language
}

\author{
PASQUALE BASTA \\ Pontifical Urbaniana University, Rome \\ donpasqualebasta@gmail.com \\ ORCID: 0000-0003-3972-5853
}

\begin{abstract}
The studies on the literary genre "gospel" are often compared with the socalled Greco-Roman bioi and popular literature. The points of contact are numerous and undeniable. As well as the differences and peculiarities of the gospels, whose link with the Hebrew Bible is a unicum to be taken into account. In particular, the typology, with its network of references, makes the canonical gospels a text proceeding through continuous phenomena of association and repetition with the ancient Scriptures. As result, the narrative takes on particular tones insofar as it indulges little in the chronicle, concentrating rather on the richness of meaning hidden in entire story of Christ. Consequently, the gospels are evidence of a mixed genre, having some characteristics of the Greco-Roman bioi and contemporary popular Lives, together with constant re-elaboration of OT elements reread and applied in a typological key. And it could not be otherwise because the events and the protagonist of the gospels perfectly intersect the horizontal and vertical dimensions of a story merging with the eternal.
\end{abstract}

KeYwORDs: Gospels, literary genre, Greco-Roman bioi, volks literature, typology

T here are many different and well-known types of language within Scripture, from saga to epic, from psalm to oracle, from proverb to parable, to name but a few, but it remains a matter of absolute consideration that the "gospel" is a very particular form of language. ${ }^{1}$ By "gospel" we don't mean here the generic proclamation first made by Jesus and then spread on a vast scale by his disciples, but rather the "gospel" in its materiality, as in the case of the four canonical texts. In this article the focus will be mainly on the long-standing question of the literary genre "gospel," without having any pretension of solving the debate, but simply taking stock of the situation, discarding the less convincing hypotheses and giving space to those considerations capable to push the research forward.

1 I conducted this research together with my excellent student Elisabetta Panaro. I am indebted to her for providing me with some ideas as well as her impressive and numerous bibliographical cards. 


\section{The Literary Genre "Gospel" between Biography and Historiography}

It is not possible to understand a text without recognising its literary genre. ${ }^{2}$ Without offering a detailed status quaestionis on the matter, it's important to simply recall no unanimous agreement among scholars on how to understand the literary genre "gospel," so that some still call it a sui generis literary genre. ${ }^{3}$ However, in recent years there has been some interest in whether the gospels belong to the literary genre of the so-called Hellenistic, or rather Greco-Roman, bioi. The idea must be verified, since Justin of Nablus, in his Prima Apologia, speaking of the gospels, states that Christians, on the Lord's Day, gathered in an assembly and read the "memoirs of the Apostles." This means that, at least initially, the gospels were not considered as bioi, namely biographies about Jesus. Certainly the literary genre "gospel," created by Mark, ${ }^{5}$ although containing historical data, has no historiographical claim, at least according to the canons of modern historiography. However, it is true that the gospels share some important points of contact with the Greco-Roman bioi, such as the scansion of the protagonist's life according to génos (origins), práxeis (actions) and paideía (education). So, what can we say? Are the Gospels biography, historiography, or neither one nor the other?

2 V. Mannucci, Bibbia come Parola di Dio. Introduzione generale alla sacra Scrittura, 19 ed. (Brescia: San Paolo 2007) 89-90, recalls how Hermann Gunkel introduced form criticism into modern biblical scholarship and set out the principles and criteria needed to recognise literary genre, describing them as "a series of dominant ideas and emotions; particular stylistic formulas and syntactic forms; a typical, easily detectable vocabulary; a common vital situation (in German Sitz im Leben), from which the literary genre originates and in which it is repeated" (my translation). If H. Gunkel applied the form criticism first to the Psalms and then to Genesis, Martin Dibelius, K.L. Schmid and Rudolf Bultmann pioneeringly used it in for the Synoptic gospels and then for John. It should not be forgotten that the use of literary genres was made imperative for Catholics by Pius XII's encyclical Divino Afflante Spiritu and the Vatican II Council's dogmatic constitution Dei Verbum.

3 J.-N. Aletti, Gesù una vita da raccontare. Il genere letterario dei vangeli di Matteo, Marco e Luca (Roma: Gregorian University \& Biblical Institute Press 2017) 11: "ancora oggi ci sono esegeti per i quali i vangeli non apparterrebbero ad alcun genere letterario noto [...], secondo costoro [...] i vangeli sarebbero in effetti il prodotto diretto della fede espressa dalla Chiesa delle origini." Among the great tenors of this line cf. R. Bultmann, La storia dei vangeli sinottici (Mesagne: Dehoniane 1996); R. Bultmann, Teologia del Nuovo Testamento, 3 ed. (Brescia: Queriniana 2008). The most lapidary remains E.-M. Becker, Das Markus Evangelium im Rahmen antiker Historiographie (Tübingen: Mohr Siebeck 2006) 65, when he defines Mark "ein Werk sui generis."

4 Cf. P.F. Beatrice, Introduzione a I Padri della Chiesa (Vicenza: Istituto San Gaetano - Elledici 2009) 52.

5 M. Vironda, Gesù nel Vangelo di Marco. Narratologia e cristologia (Bologna: Dehoniane 2003) 43: "conformemente all'uso del tempo l'autore avrebbe specificato con una prefazione la creazione di un nuovo genere letterario." 


\section{Is "euagghélion" the Literary Genre of the Gospels?}

Graham N. Stanton wrote a very interesting study about the origins, meaning and lexicographic value of the term "gospel" in the days of the NT. ${ }^{6}$ While we refer you to the reading of this beautiful book, let us recall in extreme synthesis how originally euagghélion indicated neither the book nor the literary genre, but simply the message contained in the "good news." The evangelist Mark would have been the first to employ it as generic term, in accordance with the classical Greek usage also shared by the LXX.7 Paul utilises it in Gal 1:11: "I declare to you, brethren, that the gospel which I have proclaimed [...]"; in 1 Cor 15:1: "I proclaim to you, brethren, the gospel which I have proclaimed to you [...]"; and in Rom 1:1.9: "[...] proclaiming the gospel of his Son," meaning "the content of his preaching." All this allows us to affirm with reliable certainty that in the incipit of his writing ("Beginning of the Gospel of Jesus"), Mark uses the term gospel as the proclamation of Christ (message) and not as the book or literary genre (container). Also in all the other recurrences of the text (Mark 1:14.15; 8:35; $10: 29 ; 13: 10 ; 14: 9)$, the term gospel means the message; as far as its content is concerned, however, it is not possible to identify it with the paschal kerygma, the main focus of the Pauline gospel. ${ }^{8}$

Marco Vironda argues with good reason that the term lends itself to the possibility of polysemy if we take into account the content of the news and its addressee, i.e. it can be charged with several meanings depending on whether it is used in relation to the ecclesial preaching of salvation or, more strictly, to the proclamation about Jesus Christ or the proclamation brought by Jesus himself ${ }^{9}$ (considering it respectively in its subjective or objective sense). ${ }^{10}$

In any case, the first clear attestations of the use of gospel in the sense of literary form are only to be found in the middle of the second century with Jus-

6 Cf. G.N. Stanton, Gesù e il «vangelo» (Brescia: Padeia 2015).

7 Compare Isa 40:9: "Go up a high mountain, you who bring glad tidings to Zion; raise your voice with strength, you who bring glad tidings to Jerusalem. Raise your voice, do not be afraid; proclaim to the cities of Judah: 'Here is your God!"'; Isa 52:7: "How beautiful on the mountains are the feet of the messenger of glad tidings..."; Isa 60:6: "[...] all will come from Sheba [...] proclaiming the glories of the Lord"; Isa 61:1: "[...] the Lord [...] has sent me to bring glad tidings [...]."

8 Cf. D. Dormeyer, "Die Kompositionsmetapher 'Evangelium Jesu Christi, des Sohnes Gottes' Mk 1.1 Ihre theologische und literarische Aufgaben in der Jesus-Biographie des Markus," NTS 33 (1987) 452-468.

9 Cf. Vironda, Gesù nel Vangelo di Marco, 43.

10 A. Poppi, Sinossi e commento esegetico-spirituale dei quattro Vangeli (Padova: Messaggero 2012) 601 , well underlines how gospel in an objective sense designates the announcement of the coming of the kingdom of God by Jesus, while in a subjective sense it indicates the person of Jesus himself and his saving deeds. 
tin of Nablus, ${ }^{11}$ Clement of Alexandria and the Didachè. Bearing in mind that the identification of the literary genre is functional to the content it conveys, and given the absolute novelty of the narrative content of the gospels, the difficulty of establishing precisely what is the specific literary genre of the gospels is evident. The completely new content of the Gospel narrative can only lead, at first sight, to affirm that the evangelists' intent is theological and not literary.

Nevertheless, several scholars - like Clyde Weber Votaw (The Gospels and Contemporary Biographies), Moses Hadas and Morton Smith (Heroes and Gods), Charles H. Talbert (What is a Gospel?), Philip L. Shuler (A Genre for the Gospel) and finally Richard A. Burridge (What are the Gospels?) - willingly count the Gospels among biographies. ${ }^{12}$ Some call them "popular biographies," distinguishing them from historical (or literary) biographies. ${ }^{13}$

According to Burridge, in order to avoid anachronistic errors, it is essential to relate the Gospel narratives to contemporary biographies, ${ }^{14}$ since the term $b i$ ographia originated in Greece around the fifth century of our era, being used for the first time in the Life of Isidore by the Byzantine philosopher Damascius. But even if the precise noun didn't exist, it should nevertheless be noted that a large number of narrative texts that were commonly referred to as Lifes, or bioi in Greek, had already been circulating for a long time. ${ }^{15}$

According to Luciano Zappella, attempts by scholars to identify the literary genre of the gospels have led to the hypothesis of four possibilities:

i. Re-elaboration of prophetic biographies: this first genre would be justified by the anonymity of the editor, their theological dimension, and the edifying perspective;

ii. Aretalogies: narration of supernatural facts placed in a biographical context (see especially Mark and John);

iii. Christology in the form of narration: in this case, the closest precedent would be the Hellenistic Greek novel, with the fundamental difference that the theological choice prevails over the narrative one;

11 Respectively: Apologia I, 66.3 (PG 6; 429) in which Justin is the first to use the term in the plural (gospels); Dialogue 10.2 (PG 6; 496); 2 Letter 8.2-5; 15.3-7.

12 In this regard, cf. J.M. Smith, Why Bios? On the Relationship between Gospel Genre and Implied Audience (London: Bloomsbury Clark 2015) 203, considers that biographies have very well-defined formal elements, making easy to characterise this literary genre by distinguishing it from fictional tales, generically called novels. The insistence on the words and deeds of a specific individual is the hallmark of this literature. Basically, a work is perceived as a biography if it focuses on an individual who stands out (and often becomes therefore susceptible to emulation) because of his words and deeds.

13 Aletti, Gesù una vita da raccontare, 12, distinguishes between biographies and histories, classifying the Gospels among the former and the Acts of the Apostles among the latter.

14 Cf. R.A. Burridge, Che cosa sono $i$ vangeli? (Brescia: Paideia 2008) 78-88.

15 Cf. Aletti, Gesù una vita da raccontare, 12. 
iv. Biography: the gospels would have traits in common with biographies of illustrious men (a historically embodied message). ${ }^{16}$

As for the gospels of Matt, Mark, Luke and John, it is also possible to identify several literary genres in them. In the Synoptics, for example, there are prophetic and sapiential sayings, paradigms, parables, disputations, sentences, miracle stories and passion stories. According to the classification proposed by Heinrich Zimmermann, within the broader genre of the Gospel, there is room for both Tradition of the Word (prophetic sayings, sapiential sayings, precepts, parables, I-dicta, maxims of sequela) and Tradition of the Story (disputes, miracle stories, historical narratives, passion stories, composition of stories). Different is the case of Gospels of infancy (Matt 1-2; Luke 1-2), where the literary genres of genealogy, the annunciation scheme and the midrash make their appearance. ${ }^{17}$ The Gospel of John deserves a separate discourse. Although it is rightly considered to be on a par with the other three, it remains the most mature fruit of this genre of writings, because it pursues a own purpose, namely that of highlighting the glory of the Logos, ${ }^{18}$ so that it even earns the mention of the autonomous literary genre of "testimony." 19 The studies of the authors mentioned above are representative, though not the only ones, ${ }^{20}$ of those who have paid close attention to the question of the literary genre of the gospels.

\section{Between the Biol and the Gospels, Points of Contact and Differences}

The juxtaposition of biographies and gospels merits some further consideration. First of all, it should be pointed out that there is a great and substantial difference between biography and historiography, since the former does not aim at histori-

16 Cf. L. Zappella, Euanghelion, il genere letterario dei Vangeli, http://www.bicudi. net/node/45 [access: 06.02.2017].

17 According Heinrich Zimmermann's theory summarised by Mannucci, Bibbia come Parola di Dio, 92-93.

18 Cf. R. Schnackenburg, Il Vangelo di Giovanni (Brescia: Paideia 1973) I, 51-52.

19 Cf. I. de La Potterie, "San Giovanni," Introduzione al Nuovo Testamento, 2 ed. (ed. I. de La Potterie) (Brescia: Morcelliana 1971) 879-887.

20 Cf. D.E. Aune, "The Problem of the Genre of the Gospels: A Critique of C.H. Talbert's What is a Gospel?," Gospel Perspectives (eds. R.T. France - D. Wenham) (Sheffield: JSOT 1981) 9-60; R. Hurley, "Le genre 'évangile' en fonction des effets produits par la mise en intrigue de Jésus," LTP 58/2 (2002) 243-257; R.A. Burridge, What Are the Gospels? A Comparison with Graeco-Roman Biography (Grand Rapids, MI: Eerdmans 2004); M.E. Vines, The Problem of Markan Genre. The Gospel of Mark and the Jewish Novel (Atlanta, GA: Society of Biblical Literature 2002); D.B. Capes, "Imitatio Christi and the Gospel Genre," BBR 13/1 (2003) 1-19; J.A. Diehl, "What is a 'Gospel'? Recent Studies in the Gospel Genre," CBR 9/2 (2011) 171-199. 
cal reconstruction, which is rather the task of annals. Biographies have specific aspects that need to be investigated. If, in fact, we were to identify, in the ancient world, works that are in some way similar to the literary genre "gospel," we would not have to look at the main historiographical works of the time, but rather at certain biographies such as those contained in Plutarch's Parallel Lives or even Tacitus' well-known Agricola, a text which, according to many, seems to be the closest work to the canonical gospels. In these biographical books, a sequence appears in which the protagonist of the bios is described according to a scansion of the type: génos (origins); práxeis (great deeds performed); paideía (teachings handed down).

Se, come rivelano i biografi del tempo, sono le parole e le azioni a connotare principalmente il protagonista, nondimeno è vero che la maggioranza di tali narrazioni cominciano con il raccontare brevemente l'origine e l'educazione. [...] (Sia l'origine che i ragguagli relativi all'educazione del protagonista) mirano a mettere in luce le competenze (da lui) possedute [...]. (E) benché non sempre le vite inizino con i natali dei loro eroi, né forniscano necessariamente informazioni concernenti l'educazione ricevuta, tutte insistono a porre l'accento su parole e azioni, sinteticamente comprese sotto il termine práxeis. ${ }^{21}$

Something similar to the Gospels can also be found in Xenophon's Memorabilia. ${ }^{22}$ The Memorabilia are typical of episodic literature since they have characteristics that can also be found in the Gospels. In fact, in Xenophon the episodes are connected by a rather tenuous thread, they have only a small narrative frame, they have a scarce geographical and historical location, and also an insufficient characterisation of the minor characters, because what must dominate is the memory of the protagonist. These characteristics are evident in evangelical literature. The Memorabilia genre was significantly revived in the Middle Ages around the figure of St Francis of Assisi. Popular character with a great charm and following, Francis saw an enormous micro-episodic literature flourish around his humble person, which would flow into the so-called Fioretti. This was a new literary genre, very different from the more biographical and official one, used by Thomas of Celano in his Vita Prima and Vita seconda. If, in some aspects, Fioretti show some points of contact with the Gospel genre, it should be emphasized with greater strength that around Jesus of Nazareth a phenomenon similar to Franciscan literature was born, which, however, would not flow into the canonical gospels, but rather into the apocrypha and gnostic writings.

21 J.-N. Aletti, L'arte di raccontare Gesù Cristo (Brescia: Queriniana 1991) 15-16.

22 Memorabilia is a work in four books dedicated to Socrates, a collection of conversations and episodes aiming to show the figure of the philosopher as a just man, a model of wisdom and temperance, of patriotism and philanthropy. 
In Mark and Matthew the episodic nature of the plot appears stronger than in Luke and John. This aspect creates a problem because the ancient bios (Plutarch, Xenophon and Cornelius Nepos) ${ }^{23}$ is rather consequential and not episodic, i.e. presenting a clear plot. The current debate focuses precisely on this point, since scholars seem to be divided about whether or not there is any trace of the Greek-Hellenistic bios in the canonical gospels. It remains true, however, that the canonical gospels, especially Mark, share common traits both externally and internally with the formal quadrants of some biographies of the time, Plutarch above all. ${ }^{24}$

Let us turn to the details. At the external level the points of contact are interesting. The bios is first of all a narrative prose writing with a protagonist who is the main subject of the verbs, as in the case of the gospels where Jesus is the main subject of almost all the verbs that appear in them. In both literatures the protagonist is described, in addition to the génos, while carrying out his activities by means of práxeis (actions) and loghia (words). In both the bioi and the gospels there is a very global and unspecific chronological framework. In both cases reference is made to sources and testimonies about the main character. In both literatures there are sub-genre ${ }^{25}$ such as speeches or so-called "stories," i.e. tales of encounters or wonders, as in the case of miracles. A typical feature of the bios is also its range of between 5,000 and 25,000 words, a spacing within which the gospels also fall. ${ }^{26}$

23 The use of the term bios/biography is very late, since it seems to have been used for the first time in the Life of Isidore, dated to the 5th century AD.

24 Aletti, L'arte di raccontare, 39.

25 A. Fowler, Kinds of Literature. An Introduction to the Theory of Genres and Models (Oxford: Clarendon 1982) 106-118, considers that there are three levels on which genre operates, but they are always levels of function and not of meaning, which affect both composition and interpretation. The central level is what we call genre, i.e. a grouping on which there is a general consensus from the point of view of historical origins and formal and content characteristics. At a higher level, the concept of modality operates: if a genre can be defined by a name, the modality is better illustrated by the use of an adjective (e.g. tragic opera); the modality appears more extensive and vague, it never implies a particular external form or structure and comprises only a selection of the peculiarities of the genre. Thirdly, the lowest and most circumscribed level is the subtype or subgenre, which is usually defined by a particular subject or content. A representation of these levels of genre must show outward movements, with genre at the centre: mode (motifs and styles) $\rightarrow$ genre (form and content) $\leftarrow$ subgenre (subject and matter). Richard A. Burridge (What are the Gospels?, 241) states: "This approach, applied to the gospels, clarifies many of the proposed links with other forms of literature. Many of the possible genres envisaged for the gospels are in fact relations at the level of modality: the dramatic, tragic or tragicomic elements (modality) do not therefore make the gospels dramas or tragedies (genre), any more than concepts proper to the parable make them parables."

26 Burridge (What are the Gospels?, 197-198) points out that Mark, with his 11,242 words, is close to the average length of the Greco-Roman bioi (10,000-11,000 words), while Luke and Matthew, whose gospels are more extended, counting respectively 19,428 and 18,305 words, are more reminiscent of Plutarch's longer Lives such as Alexander or Antony. For the numerical count of words 
Internally, it is possible to see how the bios embraces the whole life of the character from his birth (or the beginning of his public life) to the day of his death. This is also the case in the gospels, taking into account the necessary differentiations. Moreover, the ancient bios insists particularly on the práxeis of the protagonist, which represent the most extensive and also the best elaborated section of the entire text. ${ }^{27}$

A reason often referred to in order to contest the hypothesis that the gospels are biographies concerns the distribution of space. In this regard Burridge has pointed out that little or nothing is said about the first thirty years of Jesus' life, while afterwards a great deal of space is given to his death. ${ }^{28}$ In this respect Mark, lacking both génos and paideia, would seem to be among the Synoptics the gospel formally furthest removed from Greek-Hellenistic biographies. In fact, in many ancient biographies, the first thirty or forty years of the subject's life are sometimes treated briefly or even omitted, unlike the death scene to which, on the contrary, so much space is devoted as to appear even disproportionate. Burridge has also demonstrated how, in comparison with contemporary biographies of similar extension, which distribute práxeis over several years, even in Mark the balances are quantitatively respected in an almost equivalent manner. On the contrary, in the Gospel of Mark the práxeis of Jesus are evenly distributed throughout the narrative, except for the initial part, which is very quick, consisting of 13 verses, representing only $2 \%$ of the total. In graphics ${ }^{29}$ :

\begin{tabular}{|l|l|c|}
\hline Mark 1:1-13 & preparation and beginnings & $2.0 \%$ \\
\hline Mark 1:14-3:6 & Jesus' Galilean ministry & $9.9 \%$ \\
\hline Mark 3:7-6:6 & call of the disciples and ministry of Jesus & $17.9 \%$ \\
\hline Mark 6:7-8:26 & sending of mission and hardship of the disciples & $17.0 \%$ \\
\hline Mark 8:27-10:52 & journey to Jerusalem & $17.0 \%$ \\
\hline Mark 11-13 & ministry in Jerusalem & $17.1 \%$ \\
\hline Mark 14:1-16:8 & supper, passion, death and resurrection & $19.1 \%$ \\
\hline
\end{tabular}

in the gospels, cf. R. Morgenthaler, Statistik des neutestamentlichen Wortschatzes (Zürich: Gotthelf 1958) table 3, 164.

27 Interestingly, Jean-Noël Aletti (L'arte di raccontare, 39) points out that from the second century onwards, the second part of the Lucan diptych was handed down precisely with the mention of Acts of the Apostles (Práxeis apostólonn).

28 Burridge, What are the Gospels?, 196: "The predominant interest in the death of Jesus goes beyond the space in which it is represented. The cross, for example, dominates Mark in its entirety, with the various predictions of the passion."

29 Burridge, What are the Gospels?, 196. 


\section{Volks Literature and the Gospels Compared}

Armin D. Baum, opposing Richard A. Burridge who takes only literary or historical biographies as models for the gospels, argues that if we really want to understand the literary genre "gospel" we must refer to popular biography rather than to Hellenistic biographies. ${ }^{30}$ In his view, the gospels are literature designed for simple people, for readers of modest intellectual standing. As evidence of the existence of the genre of "popular biography," denied by some because the majority of people belonging to the working classes were unlettered or even illiterate, there are nevertheless numerous literary works that seem to go in this direction, with the biography of the fable-maker Aesop being the forerunner of this further literary genre. It is surprising that even this type of writing reveals several feae tures in common with our gospels.

In particular, one of the traits of volks literature is that the characters described were generally unknown to the general public. Jesus himself seems not to have been so well known in his own time, as can be seen from the remarkable lack of mention of him in the great historical sources of his time, such as Josephus Flavius and others, who give him only a few brief mentions. ${ }^{31}$ Jesus did not become part of the main chronicle of his time, but moved mostly in exquisitely popular circles, where the literature on him would gradually take shape. The typical characteristics of popular literature appearing in the Gospels are ${ }^{32}$ :

\begin{tabular}{|l|}
\hline $\begin{array}{l}\text { Anonymity of the author (the oldest gospels spread in the early church do not bear } \\
\text { the name of the evangelist, whose identification appears in later documents from Muratori's } \\
\text { Canon to the research carried out by Eusebius of Caesarea) }\end{array}$ \\
\hline $\begin{array}{l}\text { Protagonist does not come from a high social class, since he is not a leader, philosopher, } \\
\text { magistrate, politician, etc. }\end{array}$ \\
\hline Episodicity (the texts in question are made up of a set of independent micro-stories) \\
\hline Direct speech and dialogues \\
\hline Protagonist tells stories within the main story itself (such as the parables in the gospels) \\
\hline Prologue and epilogue used to delimit the story \\
\hline Use of low prose (as in Mark and Matthew, but not in Luke) \\
\hline $\begin{array}{l}\text { Use of dialectal expressions (such as semitisms in the gospels) and precise rhetorical figures } \\
\text { (such as parallelism or chiasmus) }\end{array}$ \\
\hline Presence of many teachings and didactics \\
\hline
\end{tabular}

30 Cf. A.D. Baum, "Biographien im alttestamentlisch-rabbinischen Stil. Zur Gattung der neutestamentlichen Evangelien," Bib 94 (2013) 534-564.

31 As proof cf. J.P. Meier, A Marginal Jew. Rethinking the Historical Jesus (New York: Doubleday 1991-2016) (five-volume work: The Roots of the Problem and the Person; Mentor, Message, and Miracles; Companions and Competitors; Law and Love; Probing the Authenticity of the Parables).

32 Cf. Aletti, L'arte di raccontare, 19-20. 
Particular emphasis should be placed on the notion of episodicity. In ancient folk biographies there is an almost complete absence of any intention of exhaustiveness on the part of the narrator. The protagonist of popular life, as well as of the Gospel story, is characterised, through his words and actions, but the biography avoids an indiscriminate accumulation of episodes concerning him, proceeding rather by choosing what seems to be the most representative. In other words, it proceeds by selection, because the attention of the volks literature concerns the protagonist because what really interests is what he represents, with the moral component in the absolute foreground. ${ }^{33}$ This explains the articulation of these narratives:

in episodi relativamente indipendenti gli uni dagli altri, [...] (i quali) non concorrono a formare una trama che si sviluppi in modo continuo e progressivo, ma si limitano piuttosto ad illustrare una tesi o un progetto d'insieme. Dal momento che si tratta di vite non sorprenderà [...] (che) questi racconti per lo più esordiscano con la nascita e terminino con la morte dei loro protagonisti (o addirittura con le connesse vicende postume). Ciò detto, quantunque la serie dei fatti narrati venga spesso regolata in base a uno schema cronologico, tale ordinamento non costituisce un elemento obbligatorio poiché, se è vero che alcune biografie procedono in base alla successione degli avvenimenti più rilevanti, altre si sviluppano maggiormente per temi, e infine altre ancora $[\ldots]$ iniziano con un andamento cronologico per concludersi seguendo un ordine tematico. ${ }^{34}$

Another common feature of the two types of narrative (popular and evangelical, at least in the Synoptics) seems to be that both do not denounce their sources, nor do they comment on their degree of reliability. The reasons for this deficiency can probably be found in the lack of historiographic intentions. Why this silence?

\section{The Gospels and the Hebrew Bible}

Once pointed out that there is a certain closeness between the gospels and the Greek-Hellenistic bioi, between the gospels and volks literature, it is also necessary to admit that these texts, as far as their content, are mainly inspired by Old Testament stories and motifs. Postulating this double influence, Daniel Marguerat states without hesitation that the Synoptics formally belong to the Greco-Roman biographical genre, while thematically they owe much to the Old Testament. ${ }^{35}$

33 Cf. Aletti, Gesù una vita da raccontare, 14-15.

34 Aletti, Gesù una vita da raccontare, 15.

35 D. Marguerat, La prima storia del cristianesimo. Gli Atti degli apostoli (Cinisello Balsamo: San Paolo 2002) 31. 
In support of this thesis, Armin D. Baum has pointed out the clear Old Testament influence, already in the opening lines of the Gospels. Here just some examples ${ }^{36}$ :

\begin{tabular}{|c|c|}
\hline $\begin{array}{c}\text { Mark 1:1: Beginning (arché) of the Gospel } \\
\text { of Jesus Christ, Son of God }\end{array}$ & $\begin{aligned} \text { Hos 1:2: } & \text { Beginning (archế) of the Word } \\
& \text { of the Lord to Hosea }\end{aligned}$ \\
\hline $\begin{aligned} \text { Matt 1:1: } & \text { Book (biblos) of the origin } \\
& \text { of Jesus Christ, son of David }\end{aligned}$ & $\begin{aligned} \text { Tob 1:1: } & \text { Book (biblos) of the words of Tobit } \\
& \text { (son) of Tobiel (son of Ananiel)... }\end{aligned}$ \\
\hline $\begin{array}{l}\text { Luke 1:5: In the time of Herod, king of } \\
\text { Judea, there was (egéneto) a priest }\end{array}$ & $\begin{array}{ll}\text { Jer 1:3: } & \text { And in the time of Jehoiakim, son of } \\
& \text { Josiah, a word was (egéneto) spoken... }\end{array}$ \\
\hline $\begin{array}{l}\text { John 1:1: In the beginning ( } \operatorname{arché} \text { ) was } \\
\text { the Word, and the Word was } \\
\text { with God }\end{array}$ & $\begin{array}{l}\text { Gen 1:1: In the beginning (archế) God created } \\
\text { the heavens and the earth. }\end{array}$ \\
\hline
\end{tabular}

Obviously, further examples could be given, highlighting, for example, how a whole series of intertextual references are active between Gospels and Hebrew Bible, ${ }^{37}$ most of which can be enclosed not only under the denomination of quotations, allusions or echoes, but rather under an even larger container that can rightly be called typology. We will now turn our attention to this further element of investigation, to see if it can help us to better define the literary genre "gospel."

36 Baum, "Biographien im alttestamentlisch-rabbinischen," 554.

37 L. Rodler, I termini fondamentali della critica letteraria (Milano: Mondadori 2004) 93-94, recalls how the term "intertextuality" was first used by Julia Kristeva during a conference on the languages of criticism held in Baltimore in 1966. Although intertextual interpretation was already present in the hypotheses of Ferdinand de Saussure on the dissemination of the generative verbal theme of a text; of Jurij N. Tynjanov on the evolution of the literary system by series of related works; of Michail Bachtin on interdiscursive plurivocity; of Erich Auerbach on the figurative relationship between the Old and New Testaments. None of these authors, however, defined the phenomenon of intertextuality better than Kristeva, when in her 1967 essay, The Word, Dialogue and the Novel, she repeatedly stressed how "every text is constructed as a mosaic of quotations." Lucia Rodler (ibidem, 94) summarises Kristeva's proposal in these terms: "a dialogue between the languages of the writer, the recipient and the cultural context, with the word acting horizontally, when it involves both sender and receiver, and vertically, when it is seen from the side of previous or different writers. This unlimited, heterogeneous and dynamic set of codes on the one hand overwhelmed the myth of the author's originality, while on the other hand it challenged the formalist and structuralist idea of the centred and cohesive text. [...] Moreover, by defining the sociality of literary writing, intertextuality for Roland Barthes rendered the binary system of sources that had dominated French comparativism definitively obsolete" (my translation). From that moment on, Kristeva's creature, intertextuality, continued to live on nominally, even if it took on new definitions from time to time. For a systematisation of intertextuality, which still serves as a basic model today, see the famous five distinctions into intertext, hypertext, metatext, paratext and architecture, as formulated by G. Genette, Palimpsests (Torino: Einaudi 1997). 


\section{Gospels between History and Typology}

The so-called "figural" or typological interpretation, which the German critic Erich Auerbach has re-delineated in his essays, has been experiencing a new great season of interest, after the glories of the patristic age, so much so that it is now recognised by many as an ancient but also new tool for reading the New Testament texts, above all the Gospels.

In his celebrated Mimesis, Auerbach thinks that this kind of interpretation brings new element to the ancient way of contemplating history. ${ }^{38}$ Stated this premise, he then goes on to describe the history of the concept of "figure," covering a very wide period of time from Latin antiquity to the Middle Ages. In particular, he underlines the great prominence that the idea of "figure" assumed among the Fathers of the Church. These undisputed protagonists of the earliest Christian exegesis engaged an intense interpretative activity on the Holy Scriptures, trying to continuously connect Jewish history with the new Christian era. The typological approach became for them an extraordinary hermeneutical key. This is how Auerbach defines the concept of "figure":

Figural interpretation establishes between two facts or persons a connection in which one of them not only signifies itself, but also signifies the other, while the other understands or fulfils the first. The two poles of the figure are separated in time, but are both found in time, as real facts or figures [my translation]. ${ }^{39}$

The "figure" establishes a link between two events, neither chronologically nor causally linked:

reason cannot establish horizontally, admitting for this word a temporal extension; (establishing therefore a connection) by vertically linking the two facts with divine providence, which only in this way can create a plan of history and only can give the key to its understanding. (In this way) the temporal-horizontal and causal connection of the facts is dissolved, the here and now is no longer an element of an earthly course, it is instead at the same time something that has always been and that is fulfilled in the future; and it is properly before the divine eye an eternal thing of all time, already fulfilled in fragmentary earthly events. ${ }^{40}$

The figural or typological conception of history reveals a magnificent unity, unlike classical antiquity, whose syntactic tools and temporal determinations do

\footnotetext{
38 E. Auerbach, Mimesis. Il realismo nella letteratura occidentale (Torino: Einaudi 2000) I, 83.

39 E. Gregori - I. Paccagnella (eds.), Mimesis. L'eredità di Auerbach. Atti del XXXV Convegno interuniversitario (Bressanone-Innsbruck, 5-8 luglio 2007) (Padova: Esedra 2009) 160.

40

Auerbach, Mimesis, 83-84.
} 
not know a similar relationship of time, space and cause. The "vertical" connections gradually became recognisable between every earthly event, with God completely beyond the scope of the Greco-Roman representation of history. The clash and conflict naturally arisen between the two ways of reconstructing events is obvious. The classics of ancient historiography try to carefully connect every fact by slavishly following the chronological and causal order of everything happening in the earthly sphere; Christians, and before them the Jews, see in the hiccup pattern of events a disconnection requiring continuous interpretation. Christian writers found themselves attempting to reconcile the two ways of conceiving history, educated as they were in the ancient sense of history, but also obliged to pour the new wine of Christianity into an old wineskin. The new faith could not simply be translated into the old formulas, but had to be adapted to the old traditions of thought and expression, but alongside the development of completely new literary genres.

For this reason, the use of typological interpretation of the Old Testament became a place inhabited by figures of Christ and Redemption. Already in the Pauline writings the concept and figural interpretation of Jesus was well present. ${ }^{41}$ But also the gospels soon began to focus on the various Christ figures in the Hebrew Bible: Adam, Isaac and Moses, the prophets who foretold the Messiah and his sacrifice, the Psalms of the persecuted righteous, and so on. Little by little, Christ was increasingly read and described as the fulfilment of his "figures" contained and prophetically announced in the Hebrew Bible. Concrete and real figures, but nevertheless also preliminary images with respect to a full manifestation that would take place later in history, with Jesus Christ, when the time for his coming was ripe.

\section{What History and Literary Genre in the Gospels?}

We have noted how the Gospels are not a simple biographical work, as they do not fall completely within any of the typical areas of either Greco-Roman historiography or the more modern factual investigation of individual events. But history, and this is an indubitable fact, is nevertheless the object of the composition of the Gospels. So what kind of history is it? With the parallels to the Greco-Roman bioi and to the so-called volks literature we have learned to notice how the evangelists have drawn on a formal level from certain literary productions in

41 The concept and figural interpretation of Jesus appears, for example, in 1 Cor 10, when the Jews of the desert are called typoi emon (figures of us), or in 1 Cor 15:21 and Rom 5:12 where Adam is considered typos of the Christ. 
vogue in their day, allowing themselves to be inspired by them in terms of structure, organisation and internal composition, length and proportions. With Auerbach we have learned to keep linked, in a time that we could define as "unitary," two poles of the same real, concrete "figure," which chronology keeps separate. We have also learned to take into account a new plane of history, the vertical one, where the main author and undisputed actor is Jesus Christ, whose Father God also becomes the only one capable of providing the exact key to understanding the events, recently happened in the world of men. But without entering into the obsolete category of the classical myth, understood as a type of narrative debasing the authenticity of the Gospel texts, reducing their historical significance beyond measure. With good reason, having as his object reality, and therefore history, Gianantonio Borgonovo speaks of myth as an asymptotic approach to reality, and therefore as a source of historical knowledge, although not supported by documents. ${ }^{42}$ Consequently, it becomes possible, if not necessary, to apply the criteria of historicity of modern historiography to certain mythical history, taking care to recognise the differences in qualitative terms, useful for safeguarding the respective originality. We must not forget that it is important for mythical history may not be relevant for modern historical criticism. On the other hand, it is unthinkable that the main protagonist of the biblical story, YHWH, can be directly addressed by the modern historiographer, if not through the indirect testimony of a human protagonist, or as a result of the outcome of a supernatural event. However, not denying the historicity of many biblical passages in this way does not mean to solve the problem. On the contrary, the state of the art invites us to be more active in the identification of new research methods more capable of grasping the lines of a complex historicity, certainly very different from that to which we moderns are accustomed. The choice of methodology for the study of an object already tells us the attitude the scholar will take towards the results to be achieved. Therefore, many scriptural passages cannot be analysed and studied by resorting to the methodology that the historian adopts for the reconstruction of political or social history. For Scripture, the "symbolic" method have to be used more and more, because most attentive to the characteristics of religious language, expressed mostly through symbols, as modern hermeneutical sciences have admirably taught. Theological reading and knowledge of the various forms of symbolic language seem to be the most powerful tools of investigation available today. ${ }^{43}$ For the gospels it remains extremely difficult to speak only of a mythical history, or of theological readings combined with the symbolic universe, since the historical basis is undoubted, and also externally well documented. What to do?

42 Cf. G. Borgonovo, "Bibbia e mito," Communio 218 (2008) 24.

43 Borgonovo, "Bibbia e mito," 25-26. 
Going back to what has been said about the biol, it is perhaps necessary to investigate their purpose, comparing it with gospels. Why did the ancients write Lives? Why did Christians write gospels in which their Lord is mentioned? With respect to the Greco-Roman bioi or the volks literature, one can, without fear of contradiction, discard not only the apologetic, recreational or encomiastic intent, but even the more properly historical intent. The only thing left standing is the focus on the religious purpose of these writings: the religious purpose determines an absolute claim to historical truth. ${ }^{44}$ The existence of religious norms, to which every believer refers, is based precisely on the truth of the biblical accounts. The first to have to believe in the objective truth contained in the scriptural accounts is the sacred writer himself.

The story of Ulysses is a myth through which, despite the many historical and critical objections that can be raised against the Trojan War, the effect Homer intended is nevertheless produced in the reader. Homer writes to give pleasure, he is aware of his purpose and therefore does not mind being a political liar. The sacred writers, on the other hand, had to write exactly what their faith in the truth of the transmitted tradition demanded. What they set out was not primarily aimed at the "reality" of the facts (even if they succeeded, was still a means and never an end) but at the truth of God.

The Bible's claim to truth [...] (is in fact) tyrannical, it excludes all other claims. The world of the stories of Holy Scripture does not content itself, aspiring to be the true historical reality, but claims to be the only true one, to be the world destined for exclusive domination. All other [...] historical events and orders have no title to present themselves independently; [...] it has been promised that all civilisations, all human history, must be ordered within its framework and submit to it [my translation]. ${ }^{45}$

The words used by Auerbach (claim, tyranny, domination, submission) seem paradoxical when referred to biblical literature, but they wonderfully render the sense of the discourse we are trying to make here. Whoever does not believe in the binding of Isaac, cannot use the story according to the intention for which it was written. In this lies the demand for the "subjugation" of the biblical texts (with all that is reticent and obscure in them), feeding the thirst for clarity and appeal to the reader to go deeper into something that is much deeper than mere reality. The Bible calls the reader to draw an interpretation from the story. The biblical story asks the believer to place his life in the world of the narrative, to feel and place himself in it as a real member. ${ }^{46}$

Auerbach, Mimesis, 16.

Auerbach, Mimesis, 17.

Auerbach, Mimesis, 18. 
As each reader's world moves chronologically further away from the biblical texts, this may become increasingly difficult. Moreover, the inevitable awakening of critical consciousness is increasingly transmuted into a blinkered claim of autonomy vis-à-vis the scriptural domain. Consequently, considering the biblical stories as ancient fables, whose doctrine corresponds to an image without a body, nowadays unable to penetrate the meaning of life, is the natural result of a process of "emancipation" from the biblical tyranny, desired by time and by a new conception of life, promoted by the historicist spirit and by a rationalism putting the human soul in brackets.

Only at this point, after a long journey, can we ultimately try to pronounce on the age-old question of the literary genre of the gospels. The answer will be brief. The gospels bear witness to a mixed genre, because if on the one hand they take up some of the typical features of Greco-Roman bioi and contemporary popular Lives, on the other hand they refer to the constant reworking of clear Old Testament elements reworked and applied in a typological key. And it could not be otherwise because the story and the protagonist of the gospels perfectly intersect the horizontal dimension of a story, chronologically placed according to a before and an after, with a more vertical dimension of the same that could not be rendered with the ordinary tools of any historical reconstruction, but only with the keys to reading a temporal sequentiality escaping any human temporal enlargement, rejoining before and in continuation to the eternal, of which history itself is the daughter. This form of Scripture has been given the name of gospel, good news.

\section{Bibliography}

Aletti, J.-N., Gesù una vita da raccontare. Il genere letterario dei vangeli di Matteo, Marco e Luca (Roma: Gregorian University \& Biblical Institute Press 2017).

Aletti, J.-N., L'arte di raccontare Gesù Cristo (Brescia: Queriniana 1991).

Auerbach, E., Mimesis. Il realismo nella letteratura occidentale (Torino: Einaudi 2000) I.

Aune, D.E., "The Problem of the Genre of the Gospels: A Critique of C.H. Talbert's What is a Gospel?,” Gospel Perspectives (eds. R.T. France - D. Wenham) (Sheffield: JSOT 1981) II, 9-60.

Baum, A.D., "Biographien im alttestamentlisch-rabbinischen Stil. Zur Gattung der neutestamentlichen Evangelien," Biblica 94 (2013) 534-564.

Beatrice, P.F., Introduzione a I Padri della Chiesa (Vicenza: Istituto San Gaetano - Elledici 2009).

Becker, E.-M., Das Markus Evangelium im Rahmen antiker Historiographie (Tübingen: Mohr Siebeck 2006).

Borgonovo, G., "Bibbia e mito," Communio. Rivista Internazionale di Teologia e Cultura 218 (2008) $17-29$.

Bultmann, R., La storia dei vangeli sinottici (Mesagne: Dehoniane 1996). 
Bultmann, R., Teologia del Nuovo Testamento, 3 ed. (Brescia: Queriniana 2008).

Burridge, R.A., Che cosa sono $i$ vangeli? (Brescia: Paideia 2008).

Burridge, R.A., What Are the Gospels? A Comparison with Graeco-Roman Biography (Grand Rapids, MI: Eerdmans 2004).

Capes, D.B., "Imitatio Christi and the Gospel Genre," Bulletin for Biblical Research 13/1 (2003) 1-19.

Diehl, J.A., "What is a 'Gospel'? Recent Studies in the Gospel Genre," Currents in Biblical Research 9/2 (2011) 171-199.

Dormeyer, D., "Die Kompositionsmetapher 'Evangelium Jesu Christi, des Sohnes Gottes' Mk 1.1 Ihre theologische und literarische Aufgaben in der Jesus-Biographie des Markus," New Testament Studies 33 (1987) 452-468.

Gregori, E. - Paccagnella, I. (eds.), Mimesis. L'eredità di Auerbach. Atti del XXXV Convegno interuniversitario (Bressanone-Innsbruck, 5-8 luglio 2007) (Padova: Esedra 2009).

Fowler, A., Kinds of Literature. An Introduction to the Theory of Genres and Models (Oxford: Clarendon 1982).

Genette, G., Palimpsests (Torino: Einaudi 1997).

Hurley, R., "Le genre 'évangile' en fonction des effets produits par la mise en intrigue de Jésus," Laval théologique et philosophique 58/2 (2002) 243-257.

Mannucci, V., Bibbia come Parola di Dio. Introduzione generale alla sacra Scrittura, 19 ed. (Brescia: Queriniana 2007).

Marguerat, D., La prima storia del cristianesimo. Gli Atti degli apostoli (Cinisello Balsamo: San Paolo 2002).

Meier, J.P., A Marginal Jew. Rethinking the Historical Jesus (New York: Doubleday 1991-2016) I-V.

Morgenthaler, R., Statistik des neutestamentlichen Wortschatzes (Zürich: Gotthelf 1958).

Poppi, A., Sinossi e commento esegetico-spirituale dei quattro Vangeli, 3 ed. (Padova: Messaggero 2012).

de La Potterie, I., "San Giovanni," Introduzione al Nuovo Testamento, 2 ed. (ed. I. de La Potterie) (Brescia: Morcelliana 1971) 879-887.

Rodler, L., I termini fondamentali della critica letteraria (Milano: Mondadori 2004).

Schnackenburg, R., Il Vangelo di Giovanni (Brescia: Paideia 1973) I.

Smith, J.M., Why bios? On the Relationship between Gospel Genre and Implied Audience (London: Bloomsbury Clark 2015).

Stanton, G.N., Gesù e il «vangelo» (Brescia: Padeia 2015).

Vines, M.E., The Problem of Markan Genre. The Gospel of Mark and the Jewish Novel (Atlanta, GA: Society of Biblical Literature 2002).

Vironda, M., Gesù nel Vangelo di Marco. Narratologia e cristologia (Bologna: Dehoniane 2003).

Zappella, L., Euanghelion, il genere letterario dei Vangeli, http://www.bicudi. net/node/45 [access: 06.02.2017]. 
